\title{
The Innovative Study of Jilin Province's Urban Integration Development
}

\author{
Tieyu LIANG \\ Jilin Business and Technology College, Changchun City Jilin \\ Province, China \\ Email: henryleone@163.com
}

\author{
Chunjing MA \\ Jilin Business and Technology College, Changchun City Jilin \\ Province, China
}

\begin{abstract}
As a big agricultural province, Jilin Province has a large agricultural population and agricultural land. In the process of urban integration, it is of great significance to solve the problems of migrant workers as well as land for promoting the healthy development of urban integration in Jilin Province and exploring a new economic growth point .In this process, we need to strengthen the research of urban integration, especially the study of land system, household registration system, employment system and social security system.
\end{abstract}

Keywords-urban integration; migrant workers problems;land problem

I. The connotation of integration of cities and towns in Jilin province

In August 2010,the nine session of the ten meeting of Jilin province Party committee passed the Several opinions of Promoting the overall development of Jilin characteristics of Urbanization, used the latest achievement of the research on urban integration development in China, offered directive opinions about The strategic train of thought and target, principle, system construction and integration of Urban Town Development Countermeasures of urban integration development, included reforms of household registration system, land system, Social security system and so on. As a big agricultural province, the best choice to solve the three agricultural problems, promoting the urban Integration development in Jilin province is Urbanization. This is also important content of accelerating transformation of the mode of economic development in Jilin province.

The world financial crisis reminds us, the economic growth cannot mainly depends on unsustainable external demand, but should focus on Internal demand, especially Consumption. The implementation of urban integration will create enormous consumption and investment pulling force. Transforming farmer's identity can further economic growth space, therefore, urban integration will become the new point of economic growth in Jilin province.

First of all, we need to recognize and solve outstanding problems from a big agricultural province into urban integration. Due to the institutional mechanisms reasons, migrant workers did not become the true sense of the people in the city. Case of urbanization rate improving year after year, the issue of migrant workers is the most important problem, while land is a fundamental problem in a. big agricultural province. If the problems of migrant workers and land can not correctly solve, it will affect not only the city, but also spreading to the countryside. The two problems should be solved by reforming of deep system.

\section{The institutional problems in processing of urbanization in Jilin province}

Urban integration is a new type of space interaction of regional city. It is the process and phenomenon of geographical spatial association, economic exchanges, social system, and cultural history is similar to the urban space. ${ }^{[1]}$ Urban integration is the process of economic structure, social structure and spatial structure change and transition. International experience shows that, when the urbanization rate reached $50 \%$ - $60 \%$, social contradictions will occurrence frequently, mostly appear in varying degrees of underemployment, a widening gap between rich and poor, a shortage of housing, traffic congestion, energy shortage and environmental pollution problems, which restrict the development of economy, Cause to the social problems. At present Jilin province urbanization rate has reached $53.3 \%$, and the future development goal will increase of $1 \%$ average annual, to 2020, the urbanization rate will reach $65 \%$, entered the rapid development period of urbanization. As a big agricultural province, the key problems to be solved in the rapid process of urbanization in Jilin province include:

\section{A Problems of migrant workers}

As same as world pattern,China 's urbanization development is: Urbanization is driven by industrialization, Labor force flows into the town industrial production from the intensive land agriculture. Urbanization has created a huge and especial group, migrant worker, in China in the past 30 years. It becomes a special policy already. There is nearly not such a group at all in the world except China. The so-called migrant workers, in fact are the peasants. Migrant workers is a special group, they are agriculture registered permanent residence, but engaged in non-agricultural work, they live in the city, but can not be completely into city life.

Traditionally, they are neither true peasants, nor the real workers. In the process of urbanization, we had solved the problem of rural labor surplus, but the need of housing problem did not be solved. And non-agricultural employment is relatively stable, the social security is not keeping up with. At present, there are many realistic problems in urban 
residence, founding and married to the migrant workers.

It is much more complex that migrant workers changes into urban residents, than those peasants whose land was expropriated by the demolition resettlement turns for town dweller, the reason is not only the problem of household registration. Migrant workers issues essentially include the Employment problem, house, education, household registration system and social welfare and security system.

\section{B Land problem}

To Realize urbanization in a big agricultural province, land problem is the basic problem, in particular to the land ownership and right of using problem, relates to the problem of cultivated land protection, relates to the land intensive use of land, involving the green development problems ( including rural natural features and characteristics of traditional holding ) etc. Of course, land problem is not unique to Jilin province, it is a common problem in China.

In the present land system, land property right belongs to the country, and the rural land property right is the name falls short of the reality "collective and all ", also it causes a phenomenon that the achievements of the so-called illegal small property right.

Beyond the existing househOld registration system and the land system, migrant workers must give up rural land if they want to get resident identity. Therefore, migrant workers generally do not willing to give up rural land and cut off from the country, including rural university students after graduation. All of these make it difficult to realize real rural population migration, urbanization can not be developed.

III. The solution path in process of urbanization in Jilin province

In order To promote the healthy development of Urban Integration in Jilin province, solve the system obstacle in urban integration process, we need to strengthen the urbanization system research, especially the land system, census register system, employment system and social security system. Jilin province should make full use privileges and experience of Changchun-Jilin-Tumen pilot zone, solve the outstanding problem of migrant workers and land system.

\section{A The reform of Land system}

\section{1) Unified urban and rural land ownership}

In fact, such as most other areas in China, there is neither collective economy nor public finance in Jilin province. The peasants don't concerned about land nature is collective or state-owned, they are only concerned with their own interests. Therefore the economic base has prepared for unifying urban and rural land property right. Jilin province can try first opportunity of the Changchun-Jilin-Tumen area, change rural land collective nature to state-owned properties. At the same time, protect of peasants' private property, it should be protected by law.

2) Unification of rural and urban real estate market In the current contradiction interweave situation between real estate and land market, establishing a unified land market is the key to solve rural land market, legal issues. With the expansion of urbanization, rural inevitably involved in land transactions .In the basis of unified land property rights, establishing a unified real estate market, and promoting urban and rural and element flow.

The national land market opened can solve the two-dimensional problem, one aspect of contracted management rights of rural land, land, housing is achieved truly voluntary, paid the ground is on the move, the farmer goes into town to sell land can not sell land, on the other hand, city residents can go to the countryside home, this is the real urban and rural and urban-rural integration. When unified urban and rural land market sets up, it can form a good market and safeguard the interests of peasants. Urban Integration is not all peasants sell their land and flow into the city, but those in the city of obtain employment peasants city changes. So, first of all, we need settle the migrant workers who obtain employment in the city and their families.

\section{3) Urban land planning}

In the process of urbanization, urban and rural overall planning to land, land saving and intensive use of land, pay attention to solve the problem of green development. On the basis of investigation science to determine the protection of arable land, setting the base line of cultivated land protection to ensure food safety. A reasonable planning of urban spatial pattern of rural residents, including the distribution, in the town of keeping rural natural features and traditional characteristics, on the other hand, in order to create a livable environment for the center, based on the present, focus on long-term, improve the urban ecological environment quality, strengthen urban ecological construction and protection, sustainable development green road of urbanization.

\section{$B$ The reform of household registration system}

In all hinder the migrant workers identity shift factors, the household registration system is the most basic institutional constraints. All of discriminatory treatment in employment, social security and public services for migrant workers is derived from the household registration system. The Ministry of public security is the promotion of further reform proposal to eliminate urban and rural households, household register differences represent the general trend, especially the central proposes the construction socialism new countryside, and some provinces accelerate the pace of reform of household registration system. Guangdong will draw lessons from Hubei experience, accelerate advance rural comprehensive reform, Shania, Shandong, Liaoning, Fujian and other provinces, have also begun to set up a unified urban and rural household registration management system, rural population is gradually enjoy national treatment, this is already represent the general trend. At present, Jilin province, the household registration management system reform in complete province has greatly, break urban and rural and segmentation of agriculture, non agriculture two Yuan registered permanent residence management structure, and gradually establish a unified household registration management system, unified register for residence. Reduce overall town settle threshold, in the 
province within the implementation of the residence permit system.

Of course, taking into account the carrying capacity of the city, the first step is so skilled, and the stability of the employment of migrant workers. To skilled workers registered permanent residence ", causes a large amount of migrant workers to the technology development, mobilization of workers to their human capital investment enthusiasm. Further reform should cancel residence permit and local registered permanent residence difference, let the stranger really find a sense of belonging, the establishment of population information resources of the library, the implementation of the actual population dynamic management mechanism, realizes population modernization of information management. The reform of the household registration system is the most critical point is, the farmer can not only obtain the urban household registration, but also with the property to go into town obtain employment, is not to belong to own private property right to use the land in exchange for household.

\section{The reform of the housing system}

In recent years, more and more families of migrant workers, to solve the housing problem in the city, urbanization is the basic conditions. Make into town farmer truly lived has its home, make a farmer truly from the country, become the city residents live up to one's name, to thoroughly realize urbanization. The reform of the housing system is the core of the establishment of the urban low-income housing security system, at the same time by supporting the differential housing credit and tax policy.

\section{The reform of social security system}

Urban integration is not only a simple household.On the reform of the household registration management system, to make the migrant workers and urban residents to enjoy the treatment of the public, accomplish equal pay for equal work, in employment, medical insurance, unemployment insurance, endowment insurance, compulsory education, enjoy the same treatment as local residents. To solve the problems of rural migrant workers should also pay attention to this special group, on one hand the development of migrant workers should pay attention to cultivate the ability, help them to improve their employability skills. Modern industry, modern service industry must be to high technology, high value-added development, which requires a large number of skilled workers, are clearly present migrant workers skills structure cannot satisfy the demands of the market. On the other hand to gradually improve city degree of tolerance, advocate the city original residents from thoughts and feelings for migrant workers. Of course, the unified social security system needs the support of local finance.

\section{References}

[1] Chunlin CHEN, Lin MEI, Jisheng LIU, Yang HAN. Research on Urban Integration Development of Eastern Inner MONGOLIA and Northeastern Provinces in CHINA [J]. Economic Geography, 2011, (6): 920-925.

[2] Junxia LI, Shouzhi ZHANG. Study of Integration of Urban Case in Developing Areas by Yan-Long-Tu[J]. Journal of Agricultural Science Yanbian University, 2011, (6): 920-925. 